\title{
Accounting
}

\section{Increasing consumers to consumers (C2C) e-commerce in central Java, Indonesia}

\author{
Suryono Budi Santosa ${ }^{a}$, Mudiantono Mudiantono ${ }^{a}$, Crismona Fenty Murniyono ${ }^{a}$, Hersugondo \\ Hersugondo $^{a^{*}}$ and Harry Soesanto ${ }^{a}$
}

\begin{tabular}{l}
${ }^{a}$ Departement of Management, Faculty \\
\hline C H R O N I C L E \\
\hline Article history: \\
Received March 102020 \\
Received in revised format March \\
152020 \\
Accepted June 102020 \\
Available online \\
June 102020 \\
\hline Keywords: \\
Product Quality \\
Trust \\
Purchase Decision
\end{tabular}

\section{Introduction}

The rapid development of technology and communication has made it easier for humans to do their daily activities, one of which is to do activities using the internet. All aspects of human life are affected by the presence of the internet, for example in the business sector. This sector utilizes the internet to trade cheaply, quickly and easily with people around the world. Furthermore, buyers and sellers involved in e-commerce trading are no longer constrained by time in stores, geographical marketing areas, and catalog shipments (Schöder et al., 2016; Lee et al., 2019). The most publicly visited e-commerce sites are C2C e-commerce sites, namely Tokopedia, Shopee, and Bukalapak, which have been proven to rank in the top 3 categories of e-commerce in Indonesia, released by Iprice's report on the e-commerce competition map in Indonesia. C2C e-commerce sites are superior compared to others, because they provide a policy that consumers not only buy but also sell their products leading to an increase in online transactions. With the increase in online transactions, it has been recognized that the open and global nature of the web shows online transactional activity at a high level of vulnerability, uncertainty, and insecurity (Faqih 2016). In 2019, it was proven that $\mathrm{C} 2 \mathrm{C}$ e-commerce experienced a decline in web visitors which caused a decline in market share. It was later identified that there are problems and also consumer complaints (Goutam \& Gopalakrishna, 2018; Giao et al., 2020; Ha \& Nguyen, 2019).

* Corresponding author. Tel.: +622476486851

E-mail address: hersugondo@1ecturer.undip.ac.id (H. Hersugondo)
(C) 2020 by the authors; licensee Growing Science, Canada

\begin{abstract}
Online shopping is recently showing rapid development. There are a lot of e-commerce sites with several categories that appear in the community, along with changes in the way people shop from conventional shopping into virtual shopping. The most publicly visited e-commerce sites are $\mathrm{C} 2 \mathrm{C}$ e-
commerce sites, namely Tokopedia, Shopee, Bukalapak, and Elevenia. However, the popularity of $\mathrm{C} 2 \mathrm{C}$ e-commerce sites must be reviewed since there is a decrease in marketing performance and in brand share over the period 2018-2019, which can weaken and harm $\mathrm{C} 2 \mathrm{C}$ e-commerce sites. This
research was conducted to analyze the factors that influence trust, purchase intention, and transaction security to improve consumer purchasing decisions of $\mathrm{C} 2 \mathrm{C}$ e-commerce sites in Central Java. Using data from 160 respondents who had made purchases on the $\mathrm{C} 2 \mathrm{C}$ e-commerce site throughout 2019, ten
hypotheses were proposed through the Structural Equation Model (SEM) analysis. The results show that purchasing decisions were influenced by trust. Consumer trust increases if the quality of the products provided by the website is adequate, thus will shape consumer trust. A B S T R A C T
\end{abstract}

Enomics and Business, Jl. Prof. Soedharto SH Tembalang, Semarang 50239, Indonesia 


\section{Table 1}

Issues Regarding E-Commerce Shopping Sites in the Consumer To Consumer (C2C) Category

\begin{tabular}{|c|c|c|c|c|}
\hline No & Shopping Site & Date of Complaint & Complaint Media & Issue \\
\hline 1. & Tokopedia & $20^{\text {th- }}$ of June 2019 & $\begin{array}{l}\text { Consumer Media } \\
\quad \text { (Susanto) }\end{array}$ & $\begin{array}{l}\text { A smartphone worth of Rp5,100,000 received by a customer do } \\
\text { not match the chosen color, Tokopedia refuses to respond to } \\
\text { consumer complaint, and accuses the consumer of manipulating } \\
\text { the transaction. Hence, the consumer's Ovo fund is still } \\
\text { deducted. }\end{array}$ \\
\hline 2. & Shopee & $10^{\text {th }}$ of July 2019 & $\begin{array}{c}\text { Consumer Media (Liana } \\
\text { Therandhana) }\end{array}$ & $\begin{array}{l}\text { Consumer data privacy issues (personal phonebook activity } \\
\text { appears in Shopee notifications). }\end{array}$ \\
\hline 3. & Bukalapak & $15^{\text {th }}$ of Febuary 2019 & $\begin{array}{l}\text { Bukalapak.com community on } \\
\text { behalf of rachmandmc }\end{array}$ & $\begin{array}{l}\text { There was a smartphone purchase transaction but the goods did } \\
\text { not arrive. }\end{array}$ \\
\hline 4. & Elevenia & $01^{\text {st }}$ of July 2016 & $\begin{array}{l}\text { PetisiOnline.Com } \\
\text { (Kumala) }\end{array}$ & $\begin{array}{l}\text { Elevenia is regarded as doing scam because it often organizes } \\
\text { fake events. }\end{array}$ \\
\hline
\end{tabular}

Table 1 shows that there are some problems faced by $\mathrm{C} 2 \mathrm{C}$ e-commerce sites for consumers which cause disappointment and loss. In accordance with the negative problems of $\mathrm{C} 2 \mathrm{C}$ e-commerce sites, this has an impact on the decline in monthly web visitors in 2019 as follows.

Table 2

Map of C2C E-Commerce Competition in Indonesia Q1 2019 - Q3 2019

\begin{tabular}{ccccc}
\hline \multirow{2}{*}{ C2C E-Commerce Ratings } & Online store & Monthly Web Visitors & Monthly Web Visitors & Monthly Web Visitors \\
& & Q1 2019 & Q2 2019 & $140,414,500$ \\
Q3 2019 & $65,953,400$ \\
2 & Tokopedia & $137,200,900$ & $90,705,300$ & $55,964,700$ \\
3 & Bukalapak & $115,256,600$ & $89,765,800$ & $42,874,100$ \\
4 & Shopee & $74,995,300$ & $3,001,400$ & 856,700 \\
\hline & Elevenia & $3,394,400$ & Source: IPrice Group Magazine 2019
\end{tabular}

Table 2 displays a map of C2C e-commerce competition in Indonesia Q1-Q3 2019. In the final quarter there were problems experienced by all marketplaces, especially $\mathrm{C} 2 \mathrm{C}$ from Tokopedia, Shopee, Bukalapak, and Elevenia, namely a decline in web visitors. Analysis of the total decline was considered quite drastic. Of the many problems faced by $\mathrm{C} 2 \mathrm{C}$ e-commerce sites, it turns out that E-commerce IQ-based on a survey conducted by online with a total of 1,240 representatives respondents throughout Indonesia - stated that Tokopedia is the site most sought after by Indonesian consumers to buy toy category products by $9 \%$ and lifestyle and hobbies by $10 \%$. Furthermore, Shopee also became a popular site for Indonesian consumers in fashion and beauty category. Bukalapak is a site sought by consumers throughout Indonesia in the mobile \& electronics category, with a percentage of $25 \%$, followed by Tokopedia with $22 \%$. This shows that $\mathrm{C} 2 \mathrm{C}$ e-commerce sites are widely used by Indonesian people and become a convenient shopping site for consumers, because in 2019, e-commerce sites such as Tokopedia, Shopee, and Bukalapak are among the best 10 e-commerce sites in Indonesia generally, and it placed the ranking of the top 3. But on the contrary, purchase intention and purchasing decisions for $\mathrm{C} 2 \mathrm{C}$ e-commerce in 2019 tend to decrease as seen in the decrease of web visitors which has an impact on the decrease in the revenue of sellers on the $\mathrm{C} 2 \mathrm{C}$ e-commerce platform. This purpose of the study is to analyse the factors that influence trust, purchase intentions, and transaction security to improve purchasing decisions. Whereas questions of the research, include:

1. Does the quality of information affect trust?

2. Does product quality affect trust?

3. Does service quality affect trust?

4. Does trust affect perceived risk?

5. Does trust affect purchase intention?

6. Does trust affect purchasing decisions?

7. Does the perceived risk affect the purchase intention?

8. Does the purchase intention affect the purchase decision?

9. Does transaction security affect purchasing decisions?

\section{Literature review and hypotheses}

According to Gunawan et al. (2019), purchasing decisions are processes that encourage consumers to identify needs, product options, choose certain products and brands. The responsibility that must be carried out by the producer or seller is to provide the best product quality and exactly the same with the description given so customers give positive feedback of the product. Quality of service is also an important aspect given by companies in online shopping. Consumer safety issues will affect 
perceptions of trust so sellers must be able to increase security on e-commerce websites (Sharma et al., 2019; Wibowo and Dirgantaran, 2017). There are important factors to build trust in online shopping which influence purchasing decisions:

\section{The effect of information quality on trust}

Research conducted by Hassan et al. (2017) states that information quality has a positive effect on trust. Consumers with a lack of prior experience have a tendency to depend on perceptions about the quality of the website to develop initial trust. Furthermore, according to Towers and Xu (2016) and Hariguna and Berlilana (2017), that there is a positive relationship between the quality of information with online consumer trust. Websites that have adequate information quality will also have greater online trust.

$\mathrm{H}_{1}$ : The higher the quality of information, the higher the level of trust.

\section{The effect of product quality on trust}

Good product quality will cause consumers to have higher trust. The research conducted by Ziaullah et al. (2015) and Suhaily and Darmoyo (2017) state a positive relationship between product quality and trust. Product quality becomes a fundamental determinant of consumer desire to buy from e-commerce websites and leads to trust in the web.

$\mathrm{H}_{2}$ : The higher the quality of the product, the higher the level of trust.

\section{The Effect of service quality on trust}

Quality of service affects consumer trust. Good quality service will build consumer trust, and poor service quality will reduce consumer trust. Research done by Kundu and Datta (2015) states that there is a significant relationship between service quality and trust. Furthermore, the results of research conducted by Chek and Ho (2016) states that there is a relationship between service quality and trust. Thus, consumers who have trust in sellers will depend on them because of the guarantee of good service quality.

$\mathrm{H}_{3}$ : The higher the quality of service, the higher the level of trust.

\section{The effect of transaction security on trust}

Transaction security on online shopping is one of the important things that builds trust. Transaction security is a consideration of consumers in shopping online because no one is in direct control. According to Sharma et al. (2019) and Wibowo and Dirgantaran (2017), there is a positive relationship between the security of transactions towards trust. Electronic retailers must have a certain way and focus on online security controls to develop trust, and make the internet a reasonable medium for business transactions (Alam et al., 2018).

$\mathrm{H}_{4}$ : The higher the security of the transaction, the higher the level of trust.

\section{The effect of trust on perceived risk}

According to research results by Rouibah et al. (2016), risk perception is a factor that negatively affects consumer trust in online transactions. The perceived risk is a negative perception of consumers that online sellers will not meet security requirements and result in losses. Furthermore, the results of the study by Shao et al. (2019) states that there is a negative relationship between trust and risk perception.

$\mathrm{H}_{5}$ : The higher the level of trust, the lower the perception.

\section{The effect of trust on purchase intention}

Research results from Liu et al. (2019) and Al-Adwan (2019) suggest that consumer confidence has a positive effect on purchase intention. With the review, recommendations, and services provided by the sellers, consumers can feel and decide whether or not to trust the platform which will end up in the intent to purchase. Furthermore, according to Wagner Mainardes et al. (2019) consumer confidence in e-commerce has a strong influence on purchase intention.

$\mathrm{H}_{6}$ : The higher the trust, the higher the purchase intention. 
Trust is built from the beginning of interaction in e-commerce and grows when consumers and sellers communicate, so it will generate trust from by the time until consumers decide to buy (Sari \& Prasetio 2018). According to research conducted by Anggraeni and Madiawati 2016) and Wibowo et al. (2015), it is suggested that there is a strong relationship between trust in purchasing decisions. Furthermore, Prasad et al. (2017) argue that trust has a positive effect on purchasing decisions.

$\mathrm{H}_{7}$ : The higher the trust, the higher the purchase decision.

\section{The Effect of Perceived Risk on Purchase Intention}

The research conducted by Ahmed and Akhlaq (2015) states that perceived risk has a negative relationship with purchase intention. The greater the consumer's loss expectations, the higher the risk that will be felt. This results in consumers' online purchase intention being suppressed when consumers find that the transaction is risky. Furthermore, according to Mohseni et al. (2018) and Zhao et al. (2017) it is suggested that perceived risk had a negative influence on purchase intention.

$\mathrm{H}_{8}$ : The higher the perceived risk, the lower the purchase intention.

\section{The effect of purchase intention on purchase decision}

Decision making in purchases made by consumers is very dependent on the value given for certain products. According to the research conducted by Jamshida and Rajeswari (2019), it is suggested that there is a positive relationship between purchase intention and purchase decisions. Meanwhile, according to Wang et al. (2016) and Al-Adwan (2019) there is a positive relationship between purchase intention and purchase decisions.

$\mathrm{H}_{9}$ : The higher the purchase intention, the higher the purchase decision.

\section{The effect of transaction security on purchase decision}

A research conducted by Alfanur and Kadono (2019) states that there is a positive relationship between transaction security and purchasing decisions in e-commerce websites. Security in online transactions is related to consumers' perception that sellers on e-commerce sites will properly conceal information about financial transactions and personal information. Moreover, according to the study by (Riantini et al., 2019), security transactions have a positive relationship to purchasing decisions.

$\mathrm{H}_{10}$ : The higher the security of the transaction, the higher the purchase decision.

Based on identified problems and literature review, the study illustrates the influence of trust, purchase intention and transaction security to improve purchasing decisions.

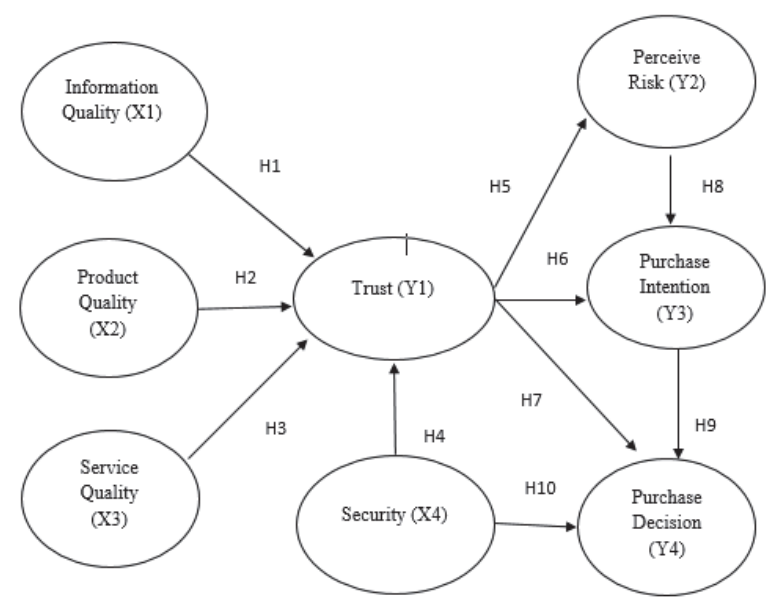

Fig. 1. The proposed study (Ingham \& Cadieux, 2016; Shao et al., 2019; Mohseni et al., 2018; Al-Adwan, 2019; Schena, 2016) 


\section{Research method}

\subsection{Research Variable}

Independent variable is a free variable that could affect dependent variable either positively or negatively. The independent variables in this research are information quality (X1), product quality (X2), service quality (X3) and transaction security (X4). However, the dependent variable is what measured and being affected by independent variables. The dependent variable in this research is purchase decision (Y4). Moreover, the intervening variable is a moderator variable that connects between independent variables and dependent variable. Intervening variables in this research are trust (Y1), perceived risk (Y2) and purchase intention (Y3).

\section{Table 3}

Variable and Research Indicator

\begin{tabular}{|c|c|c|}
\hline Variable & Indicator & $\begin{array}{l}\text { Reference } \\
\end{array}$ \\
\hline Purchase Decision (Y4) & $\begin{array}{ll}\text { Purchase Decision Indicator: } \\
\text { 1. } & \text { Constancy Decision } \\
\text { 2. } & \text { Quickly Decision } \\
\text { 3. } & \text { Confident the right decision. }\end{array}$ & 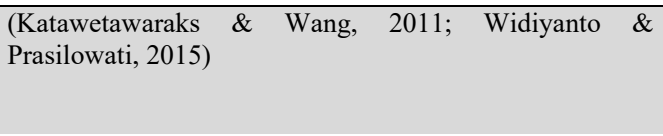 \\
\hline Purchase Intention (Y3) & 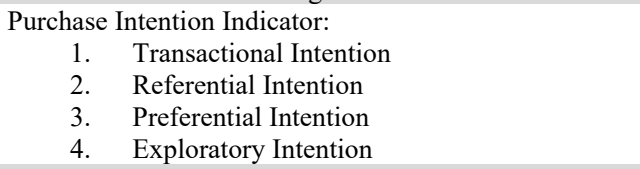 & (Ferdinand, 2002; Pourkhani et al., 2019) \\
\hline Perceive Risk (Y2) & $\begin{aligned} \text { Perceive } & \text { Risk Indicator: } \\
\text { 1. } & \text { Performance Risk } \\
\text { 2. } & \text { Financial Risk } \\
\text { 3. } & \text { Time Risk } \\
\text { 4. } & \text { Psychological Risk } \\
\text { 5. } & \text { Social Risk } \\
\text { 6. } & \text { Privacy Risk } \\
\text { 7. } & \text { System Risk }\end{aligned}$ & (Sharma \& Kurien 2017) \\
\hline Trust (Y1) & $\begin{array}{ll}\text { Trust Indicator: } \\
\text { 1. } & \text { Competence } \\
\text { 2. } & \text { Integrity } \\
\text { 3. } & \text { Virtue }\end{array}$ & (Oliveira et al., 2017) \\
\hline Transaction Security (X4) & $\begin{array}{ll}\text { Transaction Security Indicator: } \\
\text { 1. } \\
\text { 2. Authentication } \\
\text { 3. } & \text { Encryporization } \\
\end{array}$ & (Kumar \& Goyal 2016). \\
\hline Service Quality (X3) & $\begin{aligned} & \text { Service Quality Indicator: } \\
& \text { 1. } \text { Efficiency } \\
& \text { 2. } \text { System Availability } \\
& \text { 3. } \text { Fulfillment } \\
& \text { 4. } \text { Privacy }\end{aligned}$ & (Ghosh, 2018) \\
\hline Product Quality (X2) & $\begin{aligned} \text { Product } & \text { Quality Indicator: } \\
\text { 1. } & \text { Performance } \\
\text { 2. } & \text { Features } \\
\text { 3. } & \text { Conformance } \\
\text { 4. } & \text { Durability }\end{aligned}$ & (Rimawan 2017; Sukma, 2019) \\
\hline Information Quality (X1) & $\begin{array}{ll}\text { Information Quality Indicator: } \\
\text { 1. } & \text { Provides benefits Information } \\
2 . & \text { Accurate information } \\
\text { 3. } & \text { Information is easy to understand } \\
\text { 4. } & \text { Information relating to products and services }\end{array}$ & (Bao \& Huang 2018) \\
\hline
\end{tabular}

Population is defined as a combination of element and event, objects or people who have the same characteristics that because the center of attention researchers. Populations in this research are consumers e-commerce consumer-to-consumer (C2C) who made purchases at least once during the year of 2019 in Central Java. The samples in this research are 160 respondents. The method sampling is non probability sampling taken from the online and offline questionnaire. Analysis technique which is used in this research is Structural Equation Model (SEM) that operated by AMOS 23.0 program. Structural Equation Model (SEM) is a group of statistical technique that can use a measurement series of complicated relationships.

\section{Results and discussion}

The model testing used Structural Equation Modelling (SEM) in full model. It aimed to analyze the fit of model and hypotheses which are developed in this research. The model testing of SEM is conducted step by step. Based on the SEM full model testing 
can be observed some outputs that become the main benchmark whether the model is fit or not in SEM full model. Through analysis process concluded that model has fulfilled the criteria. Table 4 presents the results of full model testing.

\section{Table 4}

Result of Full Model Testing

\begin{tabular}{|c|c|c|c|}
\hline Goodness of Fit Index & Cut off Value & Analysis Result & Model Evaluation \\
\hline Chi-Square $(\mathrm{df}=436)$ & $(<485.68)$ & 450,961 & Fit \\
\hline Probabilities & $>0.05$ & 0,300 & Fit \\
\hline RMSEA & $\leq 0.08$ & 0,015 & Fit \\
\hline GFI & $\geq 0.90$ & 0,854 & Marginal \\
\hline AGFI & $\geq 0.90$ & 0,823 & Marginal \\
\hline $\mathrm{CMIN} / \mathrm{DF}$ & $\leq 2.00$ & 1,034 & Fit \\
\hline TLI & $\geq 0.95$ & 0,996 & Fit \\
\hline CFI & $\geq 0.95$ & 0,996 & Fit \\
\hline
\end{tabular}

Source: Primary data, 2020

Table 4 shows the output result of full model SEM. The results show that the model is statistically has significant results. The Chi-Square values 450.961 is smaller than the cut of value. The probability results also have confirmed that the model is accepted, that can be showed from the output values greater than 0.05 that is amounted 0.300 . Furthermore, the CMIN/DF values show that the result is smaller than 2.00 that is amounted 0.015. Moreover, the values of RMSEA, GFI, CFI, AGFI, and TLI also show that the model is accepted based on the criteria.

Table 5

Regression Weight Structural Equational

\begin{tabular}{cccc}
\hline Endogen Variable & Direct & Exogen Variable & Estimate \\
\hline Trust & $\leftarrow$ & Information Quality & -1.371 \\
Trust & $\leftarrow$ & Product Quality & 1.169 \\
Trust & $\leftarrow$ & Service Quality & .523 \\
Trust & $\leftarrow$ & Transaction Security & .453 \\
Perceive Risk & $\leftarrow$ & Trust & -.191 \\
Purchase Intention & $\leftarrow$ & Trust & .758 \\
Purchase Intention & $\leftarrow$ & Perceive Risk & -.152 \\
Purchase Decision & $\leftarrow$ & Trust & .198 \\
Purchase Decision & $\leftarrow$ & Purchase Intention & .700 \\
Purchase Decision & $\leftarrow$ & Transaction Security & .119 \\
\hline
\end{tabular}

Table 6

Direct Effect

\begin{tabular}{|c|c|c|c|c|c|}
\hline Variable Affected & & Influential Variable & C.R & $\mathrm{P}($ Sig) & Explanation \\
\hline Trust & $\leftarrow$ & Information Quality & -2.165 & 0.030 & Significant \\
\hline Trust & $\leftarrow$ & Product Quality & 2.053 & 0.040 & Significant \\
\hline Trust & $\leftarrow$ & Service Quality & 2.005 & 0.045 & Significant \\
\hline Trust & $\leftarrow$ & Transaction Security & 2.342 & 0.019 & Significant \\
\hline Perceive Risk & $\leftarrow$ & Trust & -2.226 & 0.026 & Significant \\
\hline Purchase Intention & $\leftarrow$ & Trust & 8.213 & 0.000 & Significant \\
\hline Purchase Intention & $\leftarrow$ & Perceive Risk & -2.448 & 0.014 & Significant \\
\hline Purchase Decision & $\leftarrow$ & Trust & 2.037 & 0.042 & Significant \\
\hline Purchase Decision & $\leftarrow$ & Purchase Intention & 6.994 & 0.000 & Significant \\
\hline Purchase Decision & $\leftarrow$ & Transaction Security & 2.051 & 0.040 & Significant \\
\hline
\end{tabular}

The next step is hypothesis testing. Hypothesis testing is conducted by data tabulation and used SEM analysis based on Critical Ratio (CR) value and probability $(\mathrm{P})$ value from data processed. CR value which is required greater than 1.645 and probability value smaller than 0.05 . The hypothesis testing can be seen in Table 6 . Table 6 shows that hypotheses 2,3,4,5,6,7,8,9,10 are accepted and significant. Hypothesis 1 is not accepted but is significant. That's because they have a CR greater than 1.645.

\section{Conclusion and research limitations}

The result of research can be analyzed as follows. 


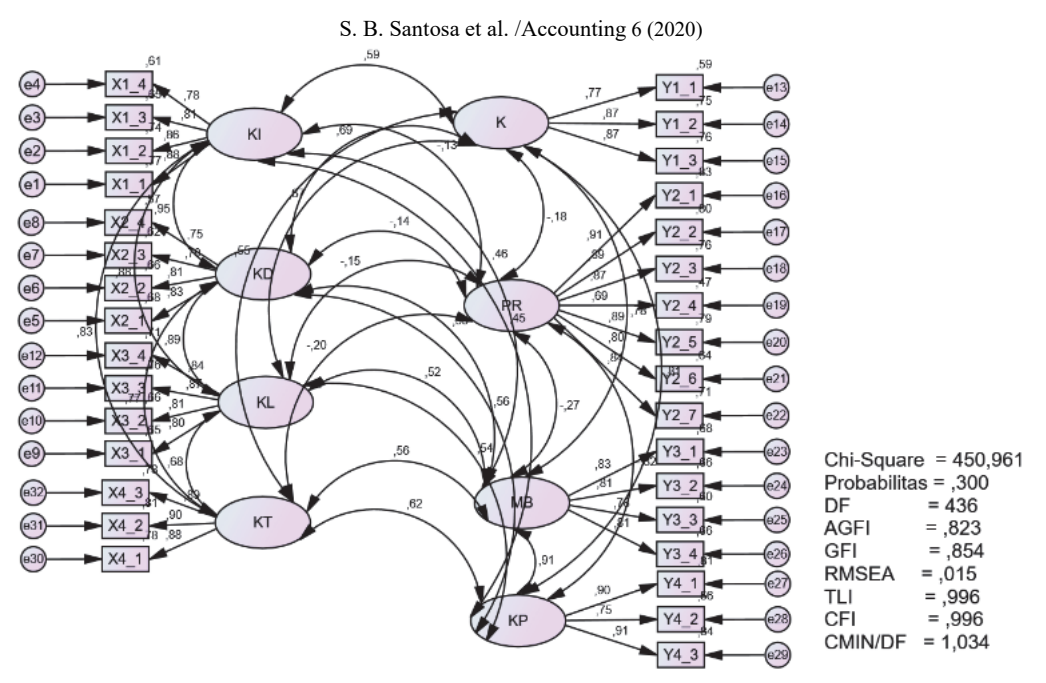

Fig. 2. The results of testing the hypotheses of the survey

Source: primary data, 2020

This research has 10 hypotheses. The hypotheses are mostly accepted and significant, but only 1 hypothesis is not accepted, namely the quality of the product against trust with a CR value greater than 1.645.

1. Hypothesis 1 explains that higher quality of information leads to higher level of trust in online shopping. This hypothesis is not suitable with the results of the hypothesis test since the data collected failed to prove the relationship between the quality of information with trust. This is supported by the answers of respondents' open questions and research (Bao \& Huang 2018), namely the presence of other variables that play a role in the relationship of info quality with trust, namely flow experience.

2. Hypothesis 2 explains that higher quality of the product leads to higher level of trust in online shopping. This result is supported by previous research conducted by Ziaullah et al. (2015) and Suhaily and Darmoyo (2017) which states there is a positive relationship between product quality and trust.

3. Hypothesis 3 explains that higher quality of services could lead to higher level of trust in online shopping. This result is supported by previous research by Kundu and Datta (2015) and Chek and Ho (2016) which states that there is a relationship between service quality and trust.

4. Hypothesis 4 explains that higher quality of services provided may lead to higher level of trust in online shopping. This result is supported by previous research by Sharma et al. (2019) and Wibowo and Dirgantara (2017) who state that there is a positive relationship between the security of transactions and trust.

5. Hypothesis 5 explains that there is a negative impact between trust and perceived risk. This result is consistent with previous research by Rouibah et al. (2016) and Shao et al. (2019) who state that risk perception is a negative factor that influences consumer confidence in online transactions.

6. Hypothesis 6 explains that the higher the consumer's trust, the higher the level of purchase intention in online shopping. This result is based on previous research from Liu et al. (2019), Al-Adwan (2019) and Wagner Mainardese et al. (2019) which suggest that consumer trust has a positive effect on purchase intention.

7. Hypothesis 7 explains that the higher the consumer's trust, the higher the level of purchasing decisions on online shopping. This result is supported by previous research by Anggraeni and Madiawati (2016) and Wibowo et al. (2015) and Prasad et al. (2017), who suggest that there is a strong relationship between trust and purchasing decisions.

8. Hypothesis 8 explains that there is a negative impact between perceived risk and purchase intention. These results are consistent with previous research by Ahmed and Akhlaq (2015), Mohseni et al. (2018), and Zhao et al. (2017) which state that risk perception has a negative relationship with purchase intention.

9. Hypothesis 9 explains that the higher the purchase intention by consumers, the higher the level of purchasing decisions in online shopping. This result is supported by previous research by Jamshida and Rajeswari (2019), Wang et al. (2016), and Al-Adwan (2019) which suggest that there is a positive relationship between purchase intention and purchasing decisions.

10. Hypothesis 10 explains that the higher the transaction security perceived by consumers, the higher the level of purchasing decisions on online shopping. This result is supported by previous research from Alfanur and Kadono (2019) and Riantini et al. (2019), who state that there was a positive relationship between transaction security and purchasing decisions on using e-commerce websites. 
This research results 6 steps or processes which can be used to increase the purchase decision. The best step is chosen to increase the purchase decision of e-commerce $\mathrm{C} 2 \mathrm{C}$ site in Central Java.

1. $\mathrm{C} 2 \mathrm{C}$ e-commerce must provide features on product information, such as stating that the product is classified as original or fake, the product must be the same as the picture and description, and further information can be seen from the testimony. If the testimony shows negative several times and could possibly harm consumers, the e-commerce can blacklist the seller in order to fix it.

2. Improve the security of e-commerce application using encryption, notification via e-mail and registered contacts, and provide full service if the goods do not arrive at the buyer or are not appropriate, such as serving refund or negotiation feature.

3. Give rewards or points to sellers who are honest on quality assurance so that it will have an impact on other sellers to follow it.

\section{References}

Ahmed, E., \& Akhlaq, A. (2015). Digital commerce in emerging economies: Factors associated with online shopping intentions in Pakistan. International Journal of Emerging Markets, 10(4), 634-647. https://doi.org/10.1108/IJoEM-01-2014-0051

Al-Adwan, A. S. (2019). Revealing the influential factors driving social commerce adoption. Interdisciplinary Journal of Information, Knowledge, and Management, 14, 295-324. https://doi.org/10.28945/4438

Alam, S., Nazim, R., Saleh, M., \& Nusari, S. (2018). Analyzing the impact of moral behavior on consumer trust : An Indian eretailing perspective. International Journal of Management and Human Science, 2(13), 24-36.

Alfanur, F., \& Kadono, Y. (2019). Analysis on e-commerce purchase intention and decision in Java and Sumatra. Proceedings of 2019 International Conference on Information Management and Technology, ICIMTech 2019, 1(August), 635-640. https://doi.org/10.1109/ICIMTech.2019.8843731

Anggraeni, P., \& Madiawati, P. N. (2016). Pengaruh kepercayaan dan kualitas informasi terhadap keputusan pembelian secara online pada situs www. traveloka. com. eProceedings of Management, 3(2).

Bao, Z., \& Huang, T. (2018). Exploring stickiness intention of B2C online shopping malls: A perspective from information quality. International Journal of Web Information Systems, 14(2), 177-192. https://doi.org/10.1108/IJWIS-10-2017-0071

Chek, Y. L., \& Ho, J. S. Y. (2016). Consumer electronics e-retailing: Why the alliance of vendors' e-service quality, trust and trustworthiness matters. Procedia - Social and Behavioral Sciences, $219, \quad 804-811$. https://doi.org/10.1016/j.sbspro.2016.05.083

Faqih, K. M. S. (2016). An empirical analysis of factors predicting the behavioral intention to adopt Internet shopping technology among non-shoppers in a developing country context: Does gender matter? Journal of Retailing and Consumer Services, 30, 140-164. https://doi.org/10.1016/j.jretconser.2016.01.016

Ghosh, M. (2018). Measuring electronic service quality in India using E-S-QUAL. International Journal of Quality and Reliability Management, 35(2), 430-445. https://doi.org/10.1108/IJQRM-07-2016-0101

Giao, H., Vuong, B., \& Quan, T. (2020). The influence of website quality on consumer's e-loyalty through the mediating role of e-trust and e-satisfaction: An evidence from online shopping in Vietnam. Uncertain Supply Chain Management, 8(2), 351-370.

Goutam, D., \& Gopalakrishna, B. (2018). Customer loyalty development in online shopping: An integration of e-service quality model and commitment-trust theory. Management Science Letters, 8(11), 1149-1158.

Gunawan, A. V., Linawati, L., Pranandito, D., \& Kartono, R. (2019). The Determinant Factors of E-Commerce Purchase Decision in Jakarta and Tangerang. Binus Business Review, 10(1), 21. https://doi.org/10.21512/bbr.v10i1.5379

Hariguna, T., \& Berlilana, B. (2017). Understanding of antecedents to achieve customer trust and customer intention to purchase e-commerce in social media, an empirical assessment. International Journal of Electrical and Computer Engineering, 7(3), 1240-1245. https://doi.org/10.11591/ijece.v7i3.pp1240-1245

Ha, N., \& Nguyen, T. (2019). The effect of trust on consumers' online purchase intention: An integration of TAM and TPB. Management Science Letters, 9(9), 1451-1460.

Hassan, A. H., Manna, R. F., \& El-Ebiary, Y. (2017). The Effect of Trust Based Factors on Using Mobile Commerce in Jordan. International Journal on Contemporary Computer Research (IJCCR), 1(2), 1-7.

Ingham, J., \& Cadieux, J. (2016). From E-shopping system quality to the consumer's intention to return: A meta-analytic study of the mediation of attitude, usefulness, enjoyment, and trust. Proceedings of the Annual Hawaii International Conference on System Sciences, 2016-March, 3556-3564. https://doi.org/10.1109/HICSS.2016.445

Jamshida, K. V., \& Rajeswari, B. (2019). The impact of C2C communication and shared information on buying decision: "A buyer's perspective." International Journal of Recent Technology and Engineering, 8(2 Special Issue 6), $634-637$. https://doi.org/10.35940/ijrte.B1122.0782S619

Katawetawaraks, C., \& Wang, C. L. (2011). Online shopper behavior influences online shoping. Asian Journal of Business Research, 1(2), 66-74. 
Kumar, D., \& Goyal, N. (2016). Security issues in M-commerce for online transaction. 2016 5th International Conference on Reliability, Infocom Technologies and Optimization, ICRITO 2016: Trends and Future Directions, 409-414. https://doi.org/10.1109/ICRITO.2016.7784990

Kundu, S., \& Datta, S. K. (2015). Impact of trust on the relationship of e-service quality and customer satisfaction. EuroMed Journal of Business, 10(1), 21-46. https://doi.org/10.1108/EMJB-10-2013-0053

Lee, K., Haque, A., Maulan, S., \& Abdullah, K. (2019). Determining intention to buy air e-tickets in Malaysia. Management Science Letters, 9(6), 933-944.

Liu, C., Bao, Z., \& Zheng, C. (2019). Exploring consumers' purchase intention in social commerce: An empirical study based on trust, argument quality, and social presence. Asia Pacific Journal of Marketing and Logistics, 31(2), $378-397$. https://doi.org/10.1108/APJML-05-2018-0170

Mohseni, S., Jayashree, S., Rezaei, S., Kasim, A., \& Okumus, F. (2018). Attracting tourists to travel companies’ websites: the structural relationship between website brand, personal value, shopping experience, perceived risk and purchase intention. Current Issues in Tourism, 21(6), 616-645. https://doi.org/10.1080/13683500.2016.1200539

Oliveira, T., Alhinho, M., Rita, P., \& Dhillon, G. (2017). Modelling and testing consumer trust dimensions in e-commerce. Computers in Human Behavior, 71, 153-164. https://doi.org/10.1016/j.chb.2017.01.050

Prasad, S., Gupta, I. C., \& Totala, N. K. (2017). Social media usage, electronic word of mouth and purchase-decision involvement. In Asia-Pacific Journal of Business Administration (Vol. 9). https://doi.org/10.1108/APJBA-06-2016-0063

Pourkhani, A., Abdipour, K., Baher, B., \& Moslehpour, M. (2019). The impact of social media in business growth and performance: A scientometrics analysis. International Journal of Data and Network Science, 3(3), 223-244.

Riantini, R. E., Andini, S., Florencia, M. M., \& Rabiah, A. S. (2019). E-Marketing Strategy Analysis of Consumer Purchase Decision in Indonesia Online Sports Stores. Proceedings of 2019 International Conference on Information Management and Technology, ICIMTech 2019, 1(August), 426-431. https://doi.org/10.1109/ICIMTech.2019.8843808

Rimawan. (2017). The Influence of Product Quality, Service Quality and Trust on Customer Satisfaction and Its Impact on Customer Loyalty (Case Study PT ABC Tbk). International Journal of Scientific \& Engineering Research, 8(7), 2330-2336.

Rouibah, K., Lowry, P. B., \& Hwang, Y. (2016). The effects of perceived enjoyment and perceived risks on trust formation and intentions to use online payment systems: New perspectives from an Arab country. Electronic Commerce Research and Applications, 19, 33-43. https://doi.org/10.1016/j.elerap.2016.07.001

Sari, P. K., \& Prasetio, A. (2018). Customer awareness towards digital certificate on E-Commerce: Does it affect purchase decision? Proceedings of the 3rd International Conference on Informatics and Computing, ICIC $2018,1-4$. https://doi.org/10.1109/IAC.2018.8780519

Schena, F. (2016). Rediscovering the Essentiality of Marketing. Springer International Publishing, 747-751. https://doi.org/10.1007/978-3-319-29877-1

Schöder, D., Ding, F., \& Campos, J. K. (2016). The Impact of E-Commerce Development on Urban Logistics Sustainability. Open Journal of Social Sciences, 04(03), 1-6. https://doi.org/10.4236/jss.2016.43001

Sfenrianto, Gunawan, W., Kelly, D. S., \& Tarigan, R. E. (2018). The use of quality, security and trust factors to improve the online purchase decision. Journal of Theoretical and Applied Information Technology, 96(5), 1436-1445.

Shao, Z., Zhang, L., Li, X., \& Guo, Y. (2019). Antecedents of trust and continuance intention in mobile payment platforms: The moderating effect of gender. Electronic Commerce Research and Applications, $33,100823$. https://doi.org/10.1016/j.elerap.2018.100823

Sharma, J., \& Kurien, D. (2017). Perceived Risk in E-Commerce: A Demographic Perspective. Nmims Management Review, 34(1), 31-57.

Sharma, S., Menard, P., \& Mutchler, L. A. (2019). Who to Trust? Applying Trust to Social Commerce. Journal of Computer Information Systems, 59(1), 32-42. https://doi.org/10.1080/08874417.2017.1289356

Suhaily, L., \& Darmoyo, S. (2017). Effect of product quality, perceived price and brand image on purchase decision mediated by customer trust (study on japanese brand electronic product). Jurnal Manajemen, 21(2), 179-194. https://doi.org/10.24912/jm.v21i2.230

Sukma, Y. (2019). The Influence of Satisfaction and Trust Customers Enterprise Sales Telkomcel Timor Leste Towards Its Loyalty Commitment. 6(1), 562-569.

Towers, N., \& Xu, K. (2016). The influence of guanxi on physical distribution service quality availability in e-commerce sourcing fashion garments from China. Journal of Retailing and Consumer Services, $28,126-136$. https://doi.org/10.1016/j.jretconser.2015.09.003

Wagner Mainardes, E., de Almeida, C. M., \& de-Oliveira, M. (2019). e-Commerce: an analysis of the factors that antecede purchase intentions in an emerging market. Journal of International Consumer Marketing, 31(5), 447-468. https://doi.org/10.1080/08961530.2019.1605643

Wang, J., Dirusso, D., Gao, J., Li, J., \& Zheng, Y. (2016). The Roles of Product Quality and Trust in Customer Satisfaction and Purchase Decision - A Study of Wechat Shopping in China. 2(3), 128-133.

Wibowo, B. A., \& Dirgantara, I. (2017). Increase Customer to Customer E-Commerce Transaction in Central Java. Advanced Science Letters, 23(8), 7274-7277.

Widiyanto, I., \& Prasilowati, S. L. (2015). Perilaku Pembelian Melalui Internet. Jurnal Manajemen Dan Kewirausahaan 
(Journal of Management and Entrepreneurship), 17(2), 109-112. https://doi.org/10.9744/jmk.17.2.109-122

Zhao, X., Deng, S., \& Zhou, Y. (2017). The impact of reference effects on online purchase intention of agricultural products. Internet Research, 27(2), 233-255. https://doi.org/10.1108/intr-03-2016-0082

Ziaullah, M., Feng, Y., \& Akhter, S. N. (2014). E-Loyalty: The influence of product quality and delivery services on e-trust and e-satisfaction in China. International Journal of Advancements in Research \& Technology, 3(10), 20-31.

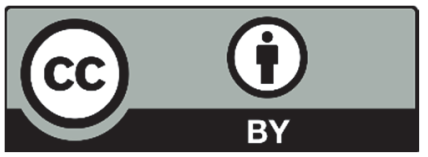

(C) 2020 by the authors; licensee Growing Science, Canada. This is an open access article distributed under the terms and conditions of the Creative Commons Attribution (CC-BY) license (http://creativecommons.org/licenses/by/4.0/). 